\title{
PELAKSANAAN PUTUSAN PENGADILAN AGAMA MENGENAI TANGJUNG JAWAB AYAH TERHADAP BIAYA PEMELIHARAAN SETELAH PERCERAIAN
}

\author{
AMRUDI \\ Universitas Amir Hamzah \\ amrudi474@gmail.com
}

\begin{abstract}
Abstrak
Islam adalah sebuah agama yang berbentuk sebuah peraturan hidup yang menjadi sumber rahmat dan kebahagiaan bagi seluruh kaum muslim. Manusia diturunkan bersama dengan peratuaran hidupnya agar tidak terjadi benturan dan ketidakseimbangan. Bantuan dan ketidakseimbangan ada ketika manusia mulai mencampakkan islam sebagai peraturan dalam hidupnya. Perkawinan merupakan salah satu perintah agama kepada yang mampu untuk segera melaksanakannya. Karena perkawinan dapat mengurangi kemaksiatan, baik dalam bentuk penglihatan maupun dalam bentuk perzinaan. Orang yang berkeinginan untuk melakukan pernikahan, tetapi belum mempunyai persiapan bekal (fisik dan nonfisik) dianjurkan Oleh Nabi Muhammad SAW, untuk berpuasa. Orang berpuasa akan memiliki kekuatan atau penghalang dari berbuat tercela yang sangat keji, yaitu perzinaan. Keluarga harus terbentuk dari pondasi yang kokoh. Pondasi tersebut adalah akidah islam, ikatan atas dasar keutamaan agama (dien). Dengan niat, cara, peroses pernikahan yang sesuai dengan syariat islam, maka restu akan menjadi doa dari semua yang menyaksikan ikatan tersebut. Maka sakinah, mawaddah, warohmah muda dicapai.

Kesimpulan Penelitian ini Bahwa anak yang belum berumur 12 tahun (mumayyiz) dibawah pengasuhan ibunya, bahwa biaya pengasuhan anak di tetapkan Rp.1.000.000.00 perbulan ditentukan karenakan mantan suami memiliki hutang pada pihak lain walaupun pengahsilan kurang dari Rp 4.000.000.00. Bahwa untuk mendapatkan sentuhan kasih sayang dari kedua orang tua yang bercerai diberi hak keduanya memberikan perhatian kasih sayang masing-masing sesuai punsinya, ibu merawat dan ayah memberi mafkah hidup. Dalam kata lain si ibu tidak berhak memonopolo pengasuhan anak tanpa memberikan kesempatan pada ayahnya.
\end{abstract}

Keyword : Tanggung jawab, biaya perceriaan, Ayah 


\section{PENDAHULUAN}

Islam memiliki pengaturan yang menyeluruh tentang kehidupan dan mengatur seluruh aspek kehidupan. Tidak kecuali masalah pernikahan, islam mengaturnya dalam sistem pergaulan. Pernikahan merpakan mengabungkan akad antara laki-laki dan perempuan yang karenanya hubungan mereka menjadi halal. Wajib menikah jika seseorang takut terjerumus dalam pelanggaran dan menjaga kesuciannya. Sunnah menikah jika seseorang memiliki kesempatan dan ingin menyelamatkan dirinya dari berbuat maksiat kepada Allah SWT.

Perkawinan ialah pekawinan lahir batin anatara seorang pria dengan seorang wanita sebagai suami isteri dengan tujuan membentuk keluarga (rumah tangga) yang bahagia dan kekal berdasarkan Ketuhanan Yang Maha Esa. Oleh karena itu, pengertian perkawinan dalam ajaran agama islam mempunyai nilai ibadah, sehingga Pasal 2 Komplikasi Hukum Islam mempunyai nilai ibadah akad yang sangat kuat (mitsqan ghalidan) untuk menaati perintah Allah, dan melaksanakannya merupakan ibadah.

\section{KAJIAN PUSTAKA}

Pada perinsipnya perkawinan bertujuan membentuk keluarga yang yang bahagia dan kekal untuk itu suami istri perlu saling membantu dan melengkapi agar masing-masing dapat mengembangkan kepribadiannya membantu dan mencapai kesejahtraan spritual maupun material karena itu undang-undang juga menganut asas atau perinsip mempersukar perceraian

Berdasarkan hadis diatas, dengan memiliki kemaslahatan dan kemudaratannya maka hukum talak ada empat, yaitu :

1. Wajib

Apabila terjadi perselisihan antara dua suami-istri dan kedua hakim emandang perlu supaya keduanya bercerai.

2. Sunnat

Apabila suami tidak sanggup lagi membayar kewajibannya (nafkahnya) dentgan cukup, atau perempuan tidak menjaga kehiormatan dirinya

3. Haram 
Dalam dua perkara : pertama memjatuhkan talak sewaktu si istri dalam keadaan haid, dan kedua menyatuhkan talak sewaktu suci yang telah dicampurinya pada waktu suci itu.

4. Makrur

Yaitu hukum asal dari pada yang tersebut dalam hadis rosullullah SAW tersebut di atas yakni perceraian dihalalkan akan tetapi dibenci oleh Allah

Cerai gugat adalah permohonan yang diajukan oleh seorang istri kepada pengadilan agama dengan maksud untuk bercerai dengan suaminya yang menjadi salah satu sebab putusnya perkawinan. Hal ini di atur dalam pasal 156 inpres RI No. Tahun 1991 tentang kompilasi Hukum islam yang menyebutkan. Bahwa Anak yang belum Mumayyiz (berusia 12 tahun) berhak mendapatkan Hadanah dari ibunya kecuali ibunya telah meninggal dunia maka kedudukannya digantikan oleh :

1. Wanita-Wanita dalam garis ke atas dari ibu.

2. Ayah.

3. Wanita-Wanita dalam garis ke atas dari ayah.

4. Saudari perempuan dari anak yang bersangkutan.

5. Wanita-Wanita kerabat sedarah menurut garis samping dari ibu.

6. Wanita-wanita kerabat sedarah menurut garis samping dari ayah.

Hukum islam menyatakan bahwa jika terjadi perceraian karena kehendak istri (gugat cerai) biaya nafkah anak tetap dibebankan kepada orang tua laki-laki (ayah) sampai anak berusia 21 tahun. Jika diperhatikan pula ketentuan pasal tersebut dengan tegas mengatur bahwa hak Hadanah terhadap anak yang belum mumayyiz (berusia 12 tahun) berada pada ibu, sedangkan bila anak sudah mumayyiz (berusia 12 tahun) dapat diserahkan kepada anak tersebut untuk memilih ikut ibu atau ayahnya.

\section{METODE PENELITIAN}

\section{Jenis Penelitian}

Pada penelitian ini penulis menggunakan jenis penelitian menggunakan metode pendekatan yuridis normatif. Pendekatan yuridis adalah pendekatan terhadap masalah dengan cara melihat peraturan perundang-undangan yang berlaku, khususnya dalam hal ini penulis melihat peraturan perundang-undangan yang mengatur masalah tanggung jawan ayah terhadap pembiayaan anak setelah terjadinya perceraian.

2. Sumber data 
Penelitian ini menggunakan data sekunder. Menurut Sugiyono (2012:402) "Sumber sekunder merupakan sumber yang tidak langsung memberikan data kepada pengumpul data, misalnya lewat orang lain atau lewat dokumen”.

\section{DISCUSSION}

\subsection{Kewajiban Hukum Orang Tua Laki-Laki (Ayah) Atas Biaya Nafkah Anak} Sah Setelah Terjadinya Perceraian

Adalah menjadi kodrat alam, manusia dilahirkan selalu hidup bersama dengan manusia lainnya didalam suatu pergaulan hidup. Hal tersebut merupakan konsekuensi dari manusia sebagai makhluk sosial. Hidup bersama seorang laki-laki dan seorang perempuan yang memenuhi syarat-syarat disebut dengan perkawinan. Subekti mengatakan bahwa perkawinan adalah pertalian yang sah antara seorang laki-laki dan seorang perempuan untuk waktu yang lama.

Perkawinan menurut Undang-Undang No. 1 Tahun 1974 adalah merupakan ikatan lahir batin antara seorang pria dengan seorang perempuansebagai suami istri dengan tujuan membentuk keluarga (rumah tangga) yang bahagia dan kekal berdasarkan Ketuhanan Yang Maha Esa.

Dari pengertian perkawinan tersebut diatas, ditemui beberapa pengertian yang terkandung didalamnya, yaitu :

Perkawinan adalah ikatan lahir batin antara seorang laki-laki (ayah) dengan seorang perempuan sebagai suami istri.

Ikatan lahir batin ditujuan untuk membentuk keluarga (rumah tangga) yang bahagia, kelak dan sejahtra.

Dasar ikatan lahir batin dan tujuan bahgia yang kekal itu berdasarkan pada Ketuhanan Yang Maha Esa.

Akan tetapi dalam perkawinan sering sekali terjadi ketidakcocokan, terjadi perselisihan dan pertengkaran yang terus menerus dan sebab-sebab lain sehingga perkawinan tidak dapat dipertahankan lagi sedangkan upaya-upaya damai yang dilakukan pihak keluarga tidak berhasil. Dalam keadaan demikian, pada akhirnya yang ditempuh adalah perceraian. 
Perceraian tentunya akan membawa akibat-akibat hukum bagi kedua belah pihak dan juga terhadap anak-anak yang dilahirkan dalam perkawinan. Anak-anak tersebut harus hidup dalam suatu keluarga dengan orang tua tunggal baik dengan seorang ibu atau dengan seorang ayah saja. Dan kadang-kadang anak harus tinggal dalam keluarga dengan ayah tiri atau ibu tiri.

Dalam hal terjadi perceraian, tentunya yang sangat urgen untuk diperhatikan adalh persoalan biaya nafkah anak. Biaya nafkah anak ini menyangkut semua hajat hidup dan keperluan yang berlaku menurut keadaan dan tempat seperti makanan, pakaian, tempat tinggal, biaya pendidikan dan lain sebagainya.

Dalam pandanga ajaran Islam, apabila istri bercerai, sedang keduanya sudah memiliki anak-anak yang belum mengrti kemashlahatan dirinya atau belum mumayyiz (berusia 12 tahun), maka ibu ank itulah yang berhak mendidik dan merawat anak itu, namun nafkah si anak tetap ditanggung oleh ayahnya. Hal tersebut selaras dengan sabda Rasilullah SAW yang artinya " kata Rasulullah SAW kepada perempuan itu : "Engkaulah yang lebih berhak untuk mendidik ankmu selama engkau belum kawin dengan orang lain". Riwayat Abu Daud dan Al Hakim

Dalam hukum islam, timbulnya kewajiban memberikan nafkah oleh orang tua laki-laki (ayah) terhadap anaknya setelah terjadi perceraian adalah karena sebab turunan. Penentuan tersebut dapat menentukan dalam Hadis Rasulullah SAW yang artinya "istri abu sofyan telah mengadukan halnya kepada Rasulullah SAW,dia berkata : Abu Sofyan seorang yang kikir, dia tidak memberi saya dan anak saya belanja selain dari pada yang saya ambil dengan tidak diketahuinya, adakah yang demikian ...mudaratkan kepada saya ? mencukupi keperluanmu dan anakmu. Sepakat Ahki Hadits".

Oleh karenanya, majelis hakim pengadilan agama dalam memeriksa dan mengadili perkara terkait dengan prinsip hukum tersebut dengan pertimbangan demi kepentingan si anak yang disesuaikan dengan kemampuan si ayah. akan tetapi pada dasarnya majelis hakim dalam memeriksa dan mengadili perkara melihat pada kasus yang dihadapinya dan tidak harus terikat pada perinsip hukum di atas. Dengan kata lain, pada dasarnya majelis hakim terikat dengan peraturan hukum yang 
berlaku, namun majelis juga bisa menyimpangi dengan argumentasi hukum/fakta yang terjadi secara kasuistis dengan memperhatikan salah satu dari tiga aspek tujuan hukum tersebut, yaitu : keadilan (aspek filosofis), yuridis (aspek kepastian hukum) dan sosiologis (aspek kemanfaatan hukum). Karena apalah gunanya hukum itu diterapkan secara tekstual kalu ternyata tidak dapat diaplikasikan dalam tindakan yang konkrit.

Dengan demikian, sesuai dengan peraturan perindang-undangan yang berlaku, orang tua perempuan dapat juga diwajibkan untuk membiayai hidup anak, jika dalam kenyataanya orang tua laki-laki (ayah) tidak mampu dalam segi ekonomi.

Menurut HUH perdata perceraian adalah putusnya ikatan perkawinan antara suami istri dengan keputusan pengadilan dan ada cukup alasan bahwa diantara suami tidak akan dapat hidup rukun lagi sebagai suami istri.

Perceraian mempunyai akibat hukum yang luas, baik dalam lapangan Hukum keluarga maupun dalam Hukum kebendaan serta Hukum perjanjian. Akibat pokok dari perceraian adalah bekas suami dan bekas istri, kemudian hidup sendiri-sendiri secara terpisah. Dalam pemutusan perkawinan dengan melalui lembaga perceraian, tentu akan menimbulkan akibat hukum diamtara suami-istri yang bercerai tersebut, dan terhadap anak serta harta dalam perkawinan yang merupakan hasil yang diperoleh mereka berdua selama perkawinan.

Adanya putusnya hubungan perkawinan karena perceraian maka akan menimbulkan berbagai kewajiban yang dibebankan kepada suami-istri masingmasing terhadapnya. Seperti yang terdapat di dalam pasal 41 undang-undang perkawinan, disebutkan bahwa akibat hukum yang terjadi karena perceraian adalah sebagai berikut :

a. Baik ibu atau bapak tetap berkewajiban memelihara dan mendidik anakanaknya, semata-mata berdasarkan kepentingan anak, bila mana ada perselisihan mengenai penguasaan anak-anak, pengadilan memberikan keputusannya.

b. Bapak yang bertanggung jawab atas semua biaya pemeliharaan dan pendidikan yang diperlukan anak itu, bila mana bapak dalam kenyataanya tidak dapat 
memenuhi kewajiban tersebut, maka pengadilan dapat menentukan bahwa ibu ikut memikul biaya tersebut.

Pengadilan dapat mewajibkan kepada bekas suami untuk memberikan biaya penghidupan dan atau menentukan sesuatu kewajiban bagi bekas istri. Oleh karena itu, dampak atau akibat putusnya hubungan perkawinan karena perceraian, telah jelas diatur dalam Undang-Undang perkawinan.

\section{KESIMPULAN}

\section{A. Kesimpulan}

Berdasarkan pada penelitian yang telah dilakukan oleh peneliti, maka diambilah kesimpulan sebagai berikut :

1. Bahwa pertimbangan hakim dalam memutus perkara No. 2042/Pdt.6/2016/PA. Mdn dalam perkara pengasuhan (hadhanah) anak sebagai berikut:

a. Bahwa anak yang belum berumur 12 tahun (mumayyiz) dibawah pengasuhan ibunya

b. Bahwa biaya pengasuhan anak di tetapkan Rp.1.000.000.00 perbulan ditentukan karenakan mantan suami memiliki hutang pada pihak lain walaupun pengahsilan kurang dari Rp 4.000.000.00.

c. Bahwa untuk mendapatkan sentuhan kasih sayang dari kedua orang tua yang bercerai diberi hak keduanya memberikan perhatian kasih sayang masingmasing sesuai punsinya, ibu merawat dan ayah memberi mafkah hidup. Dalam kata lain si ibu tidak berhak memonopolo pengasuhan anak tanpa memberikan kesempatan pada ayahnya.

2. Pelaksanaan tanggung jawab ayah terhadap anak dalam pengasuhan di bebankan Rp.1.000.000.00,setiap bulan sampai anak mumayyiz dan si ayah diberi hak utuh memberikan kasih sayang sesuai fungsinya.

\section{B. Saran}

Bahwa anak yang belum berumur 12 tahun (mumayyiz) harus diberikan perhatian oleh pemerintah melalui lemabaga terkait seperti KPAi untuk memberikan santunan psikologis dan yuridis agar si anak tidak tranmatik dan bisa percaya diri.

1. Berdasarkan fakta-fakta yuridis yang didapat selama persidangan maka penulis berpendapat bahwa putusan hakim jelas tepat dikarenakan : 
a. Bahwa anak yang belum berumur 12 tahun sesuai dengan ketentuan yuridis adalah dibawah pengawasan ibunya.

b. Ayah tetap memiliki kewajiban terhadap nafkah si anak pasca perceraian sampai kedua anak tersebut mumayyiz atau berumur 12 ataun.

c. Tuduhan terhadap mantan istrinya belum dapat dibuktikan secara faktual krenimatis perlu dibuktikan dengan bukti lain.

d. Mantan suami Penggugat sebagai PNS Militer masih memiliki penghasilan yang bisa menafkahi kedua anaknya.

2. Pelaksanaan kewajiban ayah terhadap anak yang belum berusia 12 tahun (mumayyiz) masih menyimpan masalah Hukum di karenakan seandainya tidak menepati janjinya dalam memberikan nafkah Rp. 1.000 .000 .00 perbulan diataur saksinya. Sayangnya diatur dalam Undang-undang No. 1 tahun 1974

\section{REFERENCES}

Gultom, Maidin. 2012, Perlindungan Hukum Terhadap Anak Dan Perempuan, Bandung: PT. Refika Aditama

Wadong, Maulana Hassan. 2000, Advokasi Dan Hukum Perlindungn Anak, Jakarta: PT.Grasindo

Soemitro, Roni Hanitiyo. 1990, Metodologi Penelitian Hukum Dan Jurimetri, Jakarta: Ghalia Indonesia

Surahman, Winarno. 1989, Dasar Tekhnik Riset, Bandung: Tarsito

Instruksi Presiden Republik Indonesia Nomor 1 Tahun 1991 Tentang Kompilalsi Hukum Islam. Undang-Undang Nomor 1 Tahun 1974 tentang Perkawinan.UndangUndang Nomor 23 Tahun 2002 tentang Perlindungan Anak. 